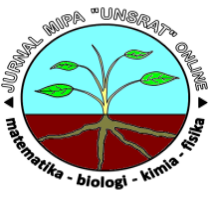

\title{
Aktivitas Antibakteri Elkstrak Metanol Tumbuhan Paku diantum capillus-veneris dan Asplenium nidus Terhadap Bakteri Gram Negatif Escherichia coli Dengan Metode Difusi Agar
}

\author{
Febby Ester Fany Kandoua, DIngse Pandiangana* \\ aJurusan Biologi, FMIPA, Unsrat, Manado
}

KATA KUNCI

Aktivitas antibakteri

Methanol

Adiantum capillus-veneris

Asplenium nidus
Escherichia coli

\begin{abstract}
A B S TR A K
Penelitian ini bertujuan untuk menguji aktivitas antibakteri ekstrak metanol tumbuhan paku Adiantum capillus-veneris dan Asplenium nidus terhadap pertumbuhan bakteri Gram negatif Escherichia coli. Pengujian aktivitas ekstrak menggunakan Metode Difusi Agar (tes Kirby Bauer), yaitu metode difusi dengan kertas cakram untuk menentukan aktivitas antimikroba. Hasil penelitian diperoleh ekstrak metanol Adiantum capillusveneris memiliki aktivitas dalam menghambat pertumbuhan Escherichia coli pada konsentrasi ekstrak 30\%,60\% dan 90\% dengan diameter zona hambat berturut-turut $0.00 \mathrm{~mm}, 0,00 \mathrm{~mm}$ dan $6,80 \mathrm{~mm}$. Ekstrak Asplenium nidus menghambat pertumbuhan Escherichia coli pada konsentrasi 30\%, 60\% dan 90\% dengan diameter zona hambat berturutturut 3,60 mm, 7,20 mm dan 12,50 mm. Berdasarkan hasil penelitian dapat disimpulkan bahwa ekstrak Adiantum capillus-veneris pada konsentrasi 90\% menghambat Escherichia coli pada kategori sedang. Ekstrak Asplenium nidus tergolong dalam kategori sedang dan kuat dalam menghambat bakteri Gram negatif Escherichia coli sehingga memiliki potensi untuk dikembangkan sebagai bahan dasar antibakteri.
\end{abstract}

KE Y W O R D

Antibacterial activity

Escherichia coli

Methanol

adiantum capillus-veneris

Asplenium nidus,
TERSEDIA ONLINE

01 Februari 2018

\section{Pendahuluan}

Tumbuhan paku memiliki keanekaragaman hayati yang cukup tinggimencapai \pm 10.000 jenis dan diperkirakan sekitar 3.000 jenis tersebar di wilayah Indonesia(Seno et al. 2012).Secara tradisional, tumbuhan paku digunakan masyarakat sebagai obat antibakteri, obat malaria, pencahar, obat penghenti pendarahan, obat pasca persalinan, obat penyakit kulit dan antiradang (Arini dan Kinho, 2012). Ibraheim et al. (2011) melaporkan Adiantumcapillus-venerisdimanfaatkan sebagai obat batuk, gangguan pernafasan, penyakit kulit, antipiretik, diuretik, antiinflamasi, antioksidan dan

*Corresponding author; Jurusan Biologi FMIPA UNSRAT, Jl. Kampus Unsrat, Manado, Indonesia 95115 Email address: febbykandou@unsrat.ac.id Published by FMIPA UNSRAT (2018) 
sebagai stimulan. Sedangkan Aspleniumbermanfaat sebagai antioksidan (Ondo et al.2013).

Khoiri (2009) menyatakan bahwa metabolit sekunder pada tumbuhan pakuadalah alkaloid, flavonoid, tanin, saponin dan steroid. Pan et al. (2011) melaporkan bahwa genus Adiantum memiliki senyawa triterpenoid, flavonoid dan steroid. Tumbuhan paku $A$. capillus-veneris memiliki senyawa flavonoid, triterpenoid, steroid dan Shikimic acids (Ibraheim et al. 2011). Aspleniumsp. memiliki senyawa tanin, alkaloid, triterpenoid dan flavonoid (Ondoet al. 2013).

Bakteri Gram negatif bersifat patogen lebih berbahaya dari bakteri Gram positif, karena pada struktur dinding selnya lebih kompleks dan berlapis tiga, yaitu lapisan luar lipoprotein, lapisan tengah lipopolisakarida, dan lapisan dalam peptidoglikan. Lapisan inimelindungi bakteri dan menghalangi masuknya obat-obatan antibiotik, salah satu contoh bakteri Gram negatif yaitu Escherichia coli.Bakteri ini biasanya terdapat pada saluran pencernaan hewan dan manusia, dan menyebabkan penyakit di saluran pencernaan dan saluran kemih. Penyakit yang disebabkan oleh E. coli antara lain diare, sepsis dan meningitis (Brookset al.2005).

$$
\text { Pemanfaatan tumbuhan }
$$

paku

Adiantumcapillus-veneris dan Aspleniumnidusyang tumbuh di Sulawesi Utara sebagai antibakteri belum dilaporkan.Oleh karena itu perlu dilakukan pengujian aktivitasekstrak Adiantumcapillus-veneris dan Aspleniumnidusterhadap pertumbuhan bakteri sebagai usaha pengembangan tumbuhan yang berpotensi sebagai obat serta menemukan sumber antibakteri baru yang berasal dari tumbuhan pakupakuan.

Tujuan penelitian menguji aktivitas antibakteri ekstrak metanol Adiantumcapillus-veneris dan Asplenium nidus terhadap pertumbuhan bakteri Gram negatif Escherichia coli.

\section{Material dan Metode}

Penelitian dilaksanakan di Laboratorium Mikrobiologi FMIPA Unsrat Manado dan pengambilan sampel di Kecamatan Langowan Kabupaten Minahasa

Alat dan bahan yang digunakanlaminar air flow, autoklaf,timbangan digital, inkubator, evaporator, blender,alat gelas, hot plate, jarum inokulasi lurus, mortar dan pestle, lemari pendingin, kertas saring, pinset, cakram kertas dengan diameter $5 \mathrm{~mm}$, jangka sorong dan kamera. Daun Adiantum capillusveneris dan Asplenium nidus, biakan murni bakteri Escherichia coli, medium Nutrient Agar (NA), medium Nutrient Broth (NB), akuades, metanol, Ampicillin dan antiseptik.

\section{Penyiapan Sampel}

Sebelum dilakukan maserasi, sampel tumbuhan Adiantum capillus-veneris dan Asplenium nidusdi identifikasi menggunakan buku de Winter dan Amoroso (2003). Selanjutnya, daun tumbuhan paku dibilas hingga bersih, dikeringanginkan, ditimbang sebanyak 50 gram, kemudian dipotong kecil dan dihaluskan. Sampel tumbuhan paku yang telah halus direndam dengan metanol selama $3 \times 24$ jam, setelah itu ekstrak disaring sehingga diperoleh filtrat. Filtrat dievaporasi sampai diperoleh ekstrak pekat. Ekstrak pekat diuapkan kembali dengan meletakkannya di wadah terbuka sehinggga diperoleh ekstrak kering. Ekstrak kering yang diperoleh dilarutkan dengan akuades sampai konsentrasinya menjadi 30\%, 60\% dan 90\%. Larutan antibiotik yaitu Ampicillin dibuat dengan cara $10 \mathrm{mg}$ Ampicillin dilarutkan dalam $10 \mathrm{ml}$ akuades (Oroh, et al. 2015).

\section{Pembuatan Medium dan Pembiakan Bakteri}

Medium yang digunakan adalah Nutrient Brothdan Nutrient Agar, dibuat disesuaikan dengan kebutuhan. Medium NB 1,95 gram dilarutkan ke dalam $150 \mathrm{ml}$ akuades, sedangkanmedium NA 10 gram dilarutkan ke dalam $500 \mathrm{ml}$ akuades, dipanaskan hingga homogen,disterilisasi dengan autoklaf pada suhu $120^{\circ} \mathrm{C}$ selama 15 menit Setelah itu medium NB dimasukkan ke dalam tabung reaksi dan medium NA kedalamcawan petri dantabung reaksi (agar miring).

Pembiakan bakteri dilakukan menurut prosedur Cappuccino (2013) yang sudah dimodifikasi. Biakan murni bakteri Escherichia coli diinokulasi secara aseptik ke dalam tabung reaksi yang berisi medium miring NA steril masing-masing tiga buah tabung reaksi, kemudian diinkubasikan pada suhu $37^{\circ} \mathrm{C}$ selama 24 jam, setelah itu diinokulasi kembali dari medium NA ke medium NB lalu diinkubasikan selama 24 jam. Larutan antibiotik Ampicillin dibuat dengan cara $10 \mathrm{mg}$ Ampicillin dilarutkan dalam 10 $\mathrm{ml}$ akuades.

\section{Uji Daya Hambat Ekstrak Terhadap Bakteri}

Pengujian aktivitas antibakteri menggunakan metode difusi agar (tes Kirby-Bauer), yaitu metode difusi dengan cakram kertas pada beberapa konsentrasi ekstrak yaitu 30\%,60\% dan 90\% dan larutanantibiotik sebagai kontrol positif dan akuades sebagai kontrol negatif. Selanjutnya dilakukan pengukuran diameter zona bening yang berada di sekitar cakram kertas, diameter zona bening yang mengelilingi cakram kertas merupakan ukuran kekuatan hambatan agen mikroba terhadap bakteri uji.Kekuatan hambatan antibakteri dapat dikategorikan sesuai ketentuan dari Davis dan Stout, 1999.Diameter zona daya hambat ekstrak tumbuhan paku disajikan dalam tabel

\section{Hasil dan Pembahasan}

Rata-rata diameter zona hambat ekstrak Adiantumcapillus-veneris dan Aspleniumnidus terhadap bakteri Gram negatif Escherichia colidapat dilihat pada Tabel 1

Hasil pengujian aktivitas ekstrak metanol daun Adiantumcapillus-veneris (Tabel 1) pada konsentrasi $30 \%$ dan $60 \%$ tidak terbentuk zona bening di sekitar cakram kertas, pada kedua konsentrasi ini belum mampu mengganggu metabolisme bakteri uji. Pada konsentrasi 90\% ekstrak metanol A.capillus-veneris menunjukkan daya hambatnya dengan kategori 
sedang $(6,80 \mathrm{~mm})$. Adiantum mengandung flavonoid, triterpenoid, steroid (Pan, et al. 2011), Shikimic acids (Ibraheim et al., 2011) dan alkaloid (Djoronga, et al. 2014) merupakan metabolit sekunder yang berpotensi sebagai antibakteri.

Tabel 1. Diameter rata-rata zona hambat ekstrak Adiantum capillus-veneris dan Asplenium nidus terhadap bakteri Escherichia coli

\begin{tabular}{|c|c|c|c|}
\hline Sampel & $\begin{array}{l}\text { Konsentrasi } \\
\text { (\%) }\end{array}$ & $\begin{array}{c}\text { Diameter } \\
\text { Zona } \\
\text { Hambat } \\
(\mathrm{mm}) \\
\end{array}$ & $\begin{array}{c}\text { Kategori } \\
\text { (Davis dan } \\
\text { Stout, } \\
1999 \text { ) } \\
\end{array}$ \\
\hline $\begin{array}{l}\text { Adiantumca } \\
\text { pillus- } \\
\text { veneris }\end{array}$ & $\begin{array}{l}30 \\
60 \\
90\end{array}$ & $\begin{array}{l}0.00 \pm 0.00 \\
0.00 \pm 0.00 \\
6.80 \pm 0.77\end{array}$ & $\begin{array}{c}- \\
\text { Sedang }\end{array}$ \\
\hline $\begin{array}{l}\text { Aspleniumni } \\
\text { dus }\end{array}$ & $\begin{array}{l}30 \\
60 \\
90\end{array}$ & $\begin{array}{c}3.60 \pm 0.24 \\
7.20 \pm 0.53 \\
12.50 \pm 0.56\end{array}$ & $\begin{array}{c}\text { Lemah } \\
\text { Sedang } \\
\text { Kuat }\end{array}$ \\
\hline $\begin{array}{l}\text { Kontrol } \\
\text { positif } \\
\text { (Ampicillin) }\end{array}$ & & 49,00 & \\
\hline $\begin{array}{l}\text { Kontrol } \\
\text { negatif }\end{array}$ & & 0,00 & \\
\hline
\end{tabular}

\section{Pengujian}

aktivitas

ekstrak

Aspleniumniduspada konsentrasi 30\% memiliki kekuatan antibakteri kategori lemah (3,60 mm), konsentrasi $60 \%$ termasuk kategori sedang $(7,20$ $\mathrm{mm}$ ) dan konsentrasi 90\% termasuk kategori kuat (12,50 mm)dapat dilihat pada Tabel 1, hal ini menandakan bahwa ekstrak memiliki aktivitas sebagai antibakteri. Menurut Rachmaniar (1997), faktor yang mempengaruhi besar kecilnya zona hambat adalah aktivitas zat antimikroba gugus fungsi dari substansi sendiri, resistensi dari bakteri terhadap sustansi zat antimikroba, kadar substansi aktif serta jumlah inokulum bakteri atau kepadatan bakteri uji. Asplenium mengandungsenyawa metabolit flavonoid, alkaloid, triterpenoid (Ondoet al., 2013; Djoronga, et al., 2014) yang berpotensi sebagai antibakteri.

Menurut Sawitti et al. 2013, besar kecilnya zona hambat yang terbentuk dapat pula dipengaruhi oleh mutu ekstrak daun. Mutu ekstrakdipengaruhi oleh faktor biologi dan faktor kimia. Faktor biologi meliputi spesies tanaman, lokasi tanaman asal, waktu pemanenan, penyimpanan bahan baku, umur serta bagian tanaman yang digunakan.

Berdasarkan hasil penelitian, ekstrak Asplenium nidusmemiliki potensi untuk dikembangkan sebagai antibakteri Gram negatif dengan melihat aktivitas penghambatannya pada beberapa konsentrasi yang berbeda.Diduga bahwa aktivitas dari ekstrak Asplenium nidusinisudah dapat merusak struktur dinding sel dari bakteri Gram negatif yang terdiri dari tiga lapisan yaitu lipoprotein, lipopolisakarida, dan peptidoglikan. Lapisan dinding sel iniberfungsi untuk melindungi bakteri dan menghalangi masuknya obat-obatan antibiotik.

\section{Kesimpulan}

Ekstrak metanol Adiantumcapillus-veneris pada konsentrasi 90\% memiliki aktivitas antibakteri kategori sedang.Ekstrak Asplenium niduspada konsentrasi $30 \%$ memiliki aktivitas antibakteri kategori lemah, konsentrasi $60 \%$ termasuk kategori sedang dan konsentrasi 90\% termasuk kategori kuat dalam menghambat bakteri Gram negatif Escherichia coli.

\section{Daftar Pustaka}

Arini D.I.D. dan Kinho J. 2012. Keragaman Jenis Tumbuhan Paku (Pteridophyta) Di Cagar Alam Gunung Ambang Sulawesi Utara. Balai Penelitian Kehutanan Manado 2 (1) 17-39.

Brooks G.F., Butel J.S., Morse S.A. 2005. Jawetz, Melnick dan Adelbergh's : Mikrobiologi Kedokteran. Jilid 1. Jakarta. Salemba Medika.

Cappuccino J.G. 2013. Manual Laboratorium Mikrobiologi. Jakarta. EGC.

de Winter W.P. dan Amoroso V.B. 2003. Plant Resources of South-East Asia no.15(2) Cryptogams : Ferns and Fern Allies. Bogor. PROSEA Foundation Bogor.

Davis W.W. dan Stout T.R. 1999. Disc Plate Method of Microbiological Antibiotic Assay. Applied Microbiology. 659-665.

Djoronga, M.I., Pandiangan, D., Kandou, F.E.F., Tangapo, A.M. 2014. Penapisan Alkaloid pada Tumbuhan Paku dari Halmahera Utara. Jurnal Mipa Unsrat Online 3(2) 102-107

Harborne J.B. 1996. Metode Fitokimia : Penuntun Cara Modern Menganalisa Tumbuhan. Bandung. Institut Teknologi Bandung.

Ibraheim Z.Z., Ahmed A.S., Gouda Y.G. 2011. Phytochemical and Biological Studies of Adiantum capillus-veneris L. Saudi Pharmaceutical Journal. 19. 65-74.

Khoiri M. 2009. Aktivitas Anti Tumor Ekstrak Etanol SelaginellaPada Sel Tumor Kelenjar Mamari Mencit (Mus musculus) C3H [Tesis]. Bogor. Institut Pertanian Bogor.

Ondo J.P., Louis C.O., Timoleon A.B., Gontran E., Jacques L. 2013. Phytochemical Screening, Total Phenolic Content and Antiradical Activity OfAsplenium africanum (Aspleniaceae) and Fruit Of Megaphrinium macrostachyum (Marantaceae). Journal Of Applied Pharmaceutical Science. 3 (08). 92-96.

Oroh, S.B., Kandou, F.E.F., Pelealu, J., Pandiangan, D. 2015. Uji Daya Hambat Ekstrak Metanol Selaginella delicatula dan Diplazium dilatatum Terhadap Bakteri Staphylococcus aureus dan Escherichia coli. Jurnal Ilmiah Sains 15(1).

Pan C., Y.G. Chen, X.Y. Ma, J.H. Jiang, F. He, Y. Zhang. 2011. Phytochemical Constituents And Pharmacological Activities Of Plants From The Genus Adiantum : A Review. Tropical Journal of Pharmaceutical Research. 10 (5). 681-692.

Pelczar M.J dan E.C.S Chan. 1988. Dasar-dasar Mikrobiologi. Jilid 2. Jakarta. UI Press.

Piggott, A.G. dan Piggott, C.J. 1988. Fern of Malaysia in Colour. Kuala Lumpur. Tropical Press SDN. BHD. Malaysia.

Rachmaniar, R. 1997. Potensi Spons Asal Kepulauan Spermonde sebagai Antimikroba. 
Seminar Perikanan Indonesia II. Ujung Pandang 2-3 Desember 1997

Sawitti M.Y., Mahatmi H dan Besung I.N.K. 2013. Daya Hambat Perasan Daun Sambiloto terhadap Pertumbuhan Bakteri Escherichia coli. Indonesia Medicus Veterinus 2(2): 142-150
Seno, A.A., Setyantoro, V dan Utami, B. 2012. Profil Karakteristik Bentuk Sorus Tumbuhan Paku di Kawasan Wisata Air Terjun Ironggolo Kabupaten Kediri. Fakultas Keguruan dan IImu Pendidikan, Universitas Nusantara PGRI Kediri 9(01): 460467 